142 AT-TAWASSUTH: Jurnal Ekonomi Islam, Volume V No. 1

Januari - Juni 2020: 142 - 162

\title{
PENGARUH OPERASI MONETER TERHADAP INFLASI DI INDONESIA
}

\author{
Nurul Jannah \\ Universitas Islam Negeri Sumatera Utara Medan \\ nuruljannah@uinsu.ac.id
}

\begin{abstract}
This study aims to determine whether there is a significant influence between monetary operations on inflation in Indonesia. This research was also conducted to find out how monetary policy in Indonesia resolves the inflationary problems that occur. The independent variable in this study is monetary operations. Monetary operations in this study include conventional and sharia monetary operations. The dependent variable in this study is inflation. The research design used is quantitative research design using simple linear regression analysis techniques supported by the classical assumption test and statistical test with the help of SPSS v22 program. The sample of this study was monetary operations and Inflation from January 2017 to Mei 2020. The result of this research showed that the data are normally distributed, and free from multicollinearity. Then this research also shows that monetary operations have significant effect on inflation. Based on the research that has been carried out, it is known that this research is very important to be carried out as a reference for the government in solving the problem of inflation in Indonesia, considering that monetary operations are policies issued by the government in minimizing inflation.
\end{abstract}

Keywords: inflation, monetary operations, open market operations, sharia monetary operations, sharia open market operations

\begin{abstract}
Abstrak
Penelitian ini bertujuan untuk mengetahui apakah terdapat pengaruh yang signifikan antara operasi moneter terhadap inflasi di Indonesia. Penelitian ini juga dilakukan untuk mengetahui bagaimana kebijakan moneter di Indonesia dalam menyelesaikan permasalaha Inflasi yang terjadi. Variabel Independen dalam penelitian ini adalah Operasi Moneter. Operasi moneter dalam penelitian ini meliputi operasi moneter konvensional dan syariah. Variable dependen dalam penelitian ini adalah Inflasi. Desain penelitian yang digunakan yaitu desain penelitian kuantitatif dengan menggunakan teknik analisis regresi linier sederhana didukung dengan uji asumsi klasik dan uji statistik dengan bantuan program SPSS 20. Sampel penelitian ini adalah Operasi Moneter dan Inflasi dari Januari 2017 sampai dengan Mei 2020. Dari hasil penelitian menunjukkan bahwa data terdistribusi secara normal, serta bebas dari multikolinearitas. Kemudian Penelitian ini juga menunjukkan bahwa operasi moneter berpengaruh signifikan terhadap inflasi. Berdasarkan penelitian yang telah dilaksanakan, diketahui bahwa penelitian ini sangat penting untuk dilakukan sebagai rujukan pemerintah dalam menyelesaikan permasalahan inflasi di Indonesia, mengingat operasi moneter merupakan kebijakan yang dikeluarkan oleh pemerintah dalam meminimalisir inflasi.
\end{abstract}


Kata kunci: Inflasi, Operasi Moneter, Operasi Pasar Terbuka, Operasi Moneter Syariah, Operasi Pasar Terbuka Syariah

\section{Pendahuluan}

Indonesia merupakan salah satu dari bagian negara berkembang di dunia, negara berkembang umumnya memiliki struktur perekonomian yang masih bercorak agraris yang cenderung masih sangat rentan terhadap goncangan kestabilan perekonomian. Salah satu permasalahan ekonomi yang sering dijumpai pada setiap negara adalah permasalahan Inflasi. Inflasi merupakan gejala ekonomi yang menjadi perhatian berbagai pihak. Inflasi tidak hanya menjadi perhatian masyarakat umum, tetapi juga menjadi perhatian dunia usaha, bank sentral, dan pemerintah.

Pada awalnya inflasi diartikan sebagai kenaikan jumlah uang beredar atau kenaikan likuiditas dalam suatu perekonomian. Pengertian tersebut mengacu pada gejala umum yang ditimbulkan oleh adanya kenaikan jumlah uang beredar yang diduga telah menyebabkan adanya kenaikan harga. Dalam pengertian tersebut, terdapat dua pengertian penting yang merupakan kunci dalam memahami inflasi. Yang pertama adalah kenaikan harga secara umum dan yang kedua adalah terusmenerus. Dalam inflasi harus terkandung unsur kenaikan harga, dan selanjutnya kenaikan harga tersebut adalah harga secara umum. Hanya kenaikan harga yang terjadi secara umum yang dapat disebut sebagai inflasi. Hal ini penting untuk membedakan kenaikan harga atas barang dan jasa tertentu. Misalnya, meningkatnya harga beras atau harga cabe merah saja belum dapat dikatakan sebagai inflasi. Inflasi adalah kenaikan harga-harga secara umum, artinya inflasi harus menggambarkan kenaikan harga sejumlah besar barang dan jasa yang dipergunakan (atau dikonsumsi) dalam suatu perekonomian. Kata kunci kedua adalah terus menerus, kenaikan harga yang terjadi karena faktor musiman, misalnya, menjelang hari-hari besar atau kenaikan harga sekali saja dan tidak mempunyai pengaruh lanjutan juga tidak dapat disebut inflasi karena kenaikan harga tersebut bukan "masalah kronis" ekonomi. ${ }^{1}$

Menurut data bank Indonesia mengenai inflasi pada tahun 2018 bahwa Indonesia masih mengalami inflasi yang terbilang tinggi setiap bulannya. Dibulan januari 2018, inflasi di Indonesia mencapai 3,25\% kemudian menurun di bulan 
144 |AT-TAWASSUTH: Jurnal Ekonomi Islam, Volume V No. 1

Januari - Juni 2020: 142 - 162

februari 2018 mencapai 3,18\% dan setelah itu terjadi kenaikan tinggi mencapai $3,40 \%$.

Tabel 1. Data Inflasi Indonesia 2018 (\%)

\begin{tabular}{|l|c|}
\hline \multicolumn{1}{|c|}{ Bulan } & Inflasi \\
\hline Januari & 3,25 \\
\hline Februari & 3,18 \\
\hline Maret & 3,40 \\
\hline April & 3,41 \\
\hline Mei & 3,23 \\
\hline Juni & 3,12 \\
\hline Juli & 3,18 \\
\hline Agustus & 3,20 \\
\hline September & 2,88 \\
\hline Oktober & 3,16 \\
\hline November & 3,23 \\
\hline Desember & 3,13 \\
\hline
\end{tabular}

Sumber : Bank Indonesia ${ }^{2}$

Untuk mengantisipasi semakin tingginya perubahan inflasi, mendorong otoritas moneter membuat kerangka kerja kebijakan moneter atau dengan kata lain Inflation Targetting Framework (ITF) dengan bertujuan untuk menjaga dan mencapai perubahan inflasi yang rendah dan stabil. Kebijakan moneter merupakan kebijakan otoritas moneter atau bank sentral dalam bentuk pengendalian besaran moneter untuk mencapai perkembangan kegiatan perekonomian yang diinginkan.

Mengingat pentingnya mengatasi masalah inflasi, maka perlu penanganan yang serius dalam pengerjaannya. Untuk mengatasi hal tersebut, hal pertama yang harus dilakukan adalah mengetahui penyebab terjadinya inflasi agar jalan untuk mengatasinya dapat diketahui. Beberapa ahli ekonomi sepakat bahwa inflasi tidak hanya berhubungan dengan jumlah uang yang beredar, akan tetapi juga berhubungan dengan jumlah barang dan jasa yang tersedia di masyarakat. Oleh sebab itu, untuk 
mengatasi masalah inflasi dibutuhkan kebijakan yang tepat. Kebijakan yang bisa diambil untuk mengatasi masalah inflasi ada tiga yaitu kebijakan moneter, kebijakan fiskal, dan kebijakan lainnya. ${ }^{3}$

Kebijakan moneter sebagai salah satu dari kebijakan ekonomi makro pada umumnya diterapkan sejalan dengan business cycle 'siklus kegiatan ekonomi'. Dalam hal ini, kebijakan moneter yang diterapkan pada kondisi dimana perekonomian sedang mengalami boom 'perkembangan yang sangat pesat' tentu berbeda dengan kebijakan moneter yang diterapkan pada kondisi dimana perekonomian sedang mengalami depression atau slump 'perkembangan yang melambat'. Dalam kajian literatur dikenal dua jenis kebijakan moneter, yaitu kebijakan moneter ekspansif dan kebijakan moneter kontraktif. Kebijakan moneter ekspansif adalah kebijakan moneter yang ditujukan untuk mendorong kegiatan ekonomi, yang antara lain dilakukan melalui peningkatan jumlah uang beredar. Sebaliknya, kebijakan moneter kontraktif adalah suatu kebijakan dalam rangka mengurangi jumlah uang yang beredar yang disebut juga dengan kebijakan uang ketat ( tight money policy ) untuk menghindari overheating. ${ }^{4}$ Saat ini Bank Indonesia memiliki dua sistem moneter dalam melakukan pengendalian jumlah uang beredar. Yang pertama operasi moneter dengan instrumeninstrumennya seperti BI rate, Operasi Pasar Terbuka (OPT), dan sertifikat Bank Indonesia (SBI). Yang kedua, Bank Indonesia menambah operasi moneter yang dinamakan Operasi Moneter Syariah (OMS). Berdasarkan peraturan yang dikeluarkan Bank Indonesia nomor 20/5/PBI/2018, OMS ini memiliki beberapa instrumen diantaranya operasi pasar terbuka syariah (OPTS), transaksi repo atau reverse repo surat berharga syariah, transaksi penempatan berjangka syariah, dan Sertifikat Bank Indonesia Syariah (SBIS). ${ }^{5}$

Berikut ini adalah data kegiatan operasi moneter Bank Indonesia baik dari segi operasi moneter konvensional dan operasi moneter syariah :

Tabel 2. Operasi Moneter 2018 (Milyar Rp)

\begin{tabular}{|l|c|c|}
\hline Bulan & Operasi Moneter Konvensional & Operasi Moneter Syariah \\
\hline Januari & 508.898 & 47.244 \\
\hline Februari & 495.314 & 44.438 \\
\hline Maret & 430.534 & 44.288 \\
\hline
\end{tabular}


146 |AT-TAWASSUTH: Jurnal Ekonomi Islam, Volume V No. 1

Januari - Juni 2020: 142 - 162

\begin{tabular}{|l|c|c|} 
April & 340.860 & 39.292 \\
\hline Mei & 305.438 & 32.845 \\
\hline Juni & 273.576 & 32.643 \\
\hline Juli & 296.514 & 31.744 \\
\hline Agustus & 251.804 & 27.841 \\
\hline September & 263.103 & 38.930 \\
\hline Oktober & 286.228 & 34.079 \\
\hline November & 299.121 & 33.879 \\
\hline Desember & 243.822 & 47.186 \\
\hline
\end{tabular}

Sumber : Bank Indonesia ${ }^{6}$

Dari data operasi moneter dan OMS diatas diketahui bahwa terjadi nya penurunan pada bulan februari sampai dengan agustus 2018. Hal ini menyatakan bahwa kebijakan moneter yang diterapkan oleh Bank Indonesia seperti salah satunya operasi pasar terbuka konvensional dan syariah mengalami penurunan. Secara teori, kebijakan moneter adalah sebuah kebijakan yang diterapkan oleh Bank Indonesia untuk mengendalikan laju inflasi melalui jumlah uang beredar. Namun, jika kita perhatikan data operasi moneter dan OMS serta data inflasi tahun 2018, kita akan melihat ketidaksesuaian teori dan keadaan yang terjadi di Indonesia. Dari data diatas, kita melihat di bulan februari terjadi penurunan inflasi yaitu berkisar 3,18\% dan terjadi penurunan pada operasi moneter dan OMS di bulan februari. Hal ini menunjukkan adanya ketidaksesuaian antara teori yang seharusnya kebijakan moneter merupakan suatu kebijakan yang bertujuan untuk mengendalikan laju inflasi melalui penstabilan jumlah uang beredar.

Penelitian terdahulu yang membahas tentang operasi moneter juga telah dilakukan oleh Khairina Tambunan (2016) dengan judul analisis pengaruh investasi, operasi moneter dan ZIS terhadap Pertumbuhan Ekonomi Indonesia. Pada hasil penelitian tersebut, operasi moneter yang dijelaskan dengan data FASBIS berpengaruh terhadap pertumbuhan ekonomi di Indonesia. ${ }^{7}$ Selain itu, penelitian yang dilakukan oleh faisal affandi dengan judul penelitian analisis pengaruh tingkat inflasi, nilai tukar, BI-Rate, dan suku bunga bank konvensional terhadap margin bagi hasil deposito mudarabah perbankan syariah di Indonesia periode 2010-2015, hasil dari 
penelitian tersebut bahwa tingkat inflasi tidak berpengaruh terhadap margin bagi hasil deposito perbankan syariah. ${ }^{8}$ Dan penelitian terakhir yang membahas tentang inflasi adalah penelitian yang dilakukan oleh Nursantri Yanti dengan judul pengaruh SBI, SBIS, Inflasi dan Nilai Tukar Rupiah terhadap Transaksi Pasar Uang Antar Bank Syariah. Hasil penelitian ini menjelaskan bahwa, inflasi masuk pada kategori dominan mempengaruhi transaksi pasar uang antarbank syariah dalam jangka panjang. ${ }^{9}$ Dari ketiga penelitian terdahulu diatas tidak menjadikan inflasi sebagai variabel dependen. Maka penelitian ini akan menjadikan inflasi sebagai variabel dependennya.

\section{Kajian Literatur}

\section{Inflasi}

Inflasi adalah gejala kenaikan harga barang-barang yang bersifat umum dan terus menerus. Ini tidak berarti bahwa harga-harga berbagai macam barang itu naik dengan dengan persentase yang sama. Mungkin dapat terjadi kenaikan harga tersebut tidak bersamaan. Terdapat kenaikan harga umum barang secara terus menerus selama satu periode tertentu. Kenaikan yang terjadi hanya sekali saja, meskipun dengan persentase yang cukup besar bukanlah merupakan inflasi.

Secara umum ada tiga komponen dalam inflasi, yaitu: Kenaikan Harga Harga suatu komoditas dikatakan naik jika menjadi lebih tinggi daripada harga periode sebelumnya. Misalnya, pada musim panceklik harga beras bisa mencapai Rp 10.000,per kilogram. Sebab harga gabah telah naik. Tetapi di musim panen harganya dapat lebih murah, karena harga gabah juga biasanya lebih murah. Demikian dapat dikatakan pada musim panceklik selalu terjadi kenaikan harga beras. Begitu pula barang-barang atau jasa lainnya. Bersifat Umum Kenaikan harga suatu komoditas belum dapat dikatakan inflasi jika kenaikan tersebut tidak menyebabkan harga-harga secara umum naik. Misalnya, setiap pemerintah menaikkan harga BBM, harga-harga komoditas lain tidak turut naik. Namun jika kenaikan harga BBM mempengaruhi kenaikan harga komoditas lainnya maka hal ini menunjukkan terjadi inflasi. Berlangsung Terus-Menerus Kenaikan harga yang bersifat umum juga belum akan memunculkan inflasi, jika terjadinya hanya sesaat. Karena itu perhitungan inflasi 
148 |AT-TAWASSUTH: Jurnal Ekonomi Islam, Volume V No. 1

Januari - Juni 2020: 142 - 162

dilakukan dalam rentang waktu minimal bulanan dan berlangsung lama dan terus menerus.

Tingkat inflasi berbeda dari satu periode ke periode lainnya, dan berbeda pula dari satu negara ke negara lainnya. Masalah kenaikan harga-harga yang berlaku diakibatkan oleh banyak faktor. Di negara industri pada umumnya inflasi bersumber dari salah satu atau gabungan dari dua masalah berikut : Pertama tingkat pengeluaran agregat yang melebihi kemampuan perusahaan untuk menghasilkan barang dan jasa. Kedua, pekerja di berbagai kegiatan ekonomi menuntut kenaikan upah.

Taqiuddin Ahmad ibn al-Maqrizi (1364 M - 1441 M), menggolongkan inflasi dalam dua golongan yaitu: Natural Inflation. Inflasi jenis ini diakibatkan oleh sebabsebab alamiah, di mana orang tidak mempunyai kendali. Human Error Inflation adalah inflasi yang diakibatkan oleh kesalahan dari manusia yang menyimpang atau

melanggar dari aturan dan kaidah-kaidah syariah. ${ }^{10}$ Sebagaimana firman Allah swt yang artinya: “ Telah nampak kerusakan di darat dan di laut disebabkan karena perbuatan tangan manusia, supaya Allah merasakan kepada mereka sebahagian dari (akibat) perbuatan mereka, agar mereka kembali (ke jalan yang benar)" (QS. ArRum:41).

\section{Kebijakan Moneter}

Kebijakan moneter adalah salah satu kebijakan perekonomian yang dilakukan oleh pemerintah suatu negara dalam hal pengendalian jumlah uang yang beredar di masyarakat. kebijakan moneter ini berfungsi untuk menjaga kestabilan moneter dan pertumbuhan ekonomi. Ada beberapa aspek yang dapat dilakukan bank sentral dalam membahas kebijakan moneter, yaitu langkah-langkah yang mempengaruhi suku bunga dan langkah-langkah yang mempengaruhi penawaran uang.

Kebijakan moneter bertujuan untuk melakukan perubahan terhadap dua variabel makroekonomi utama, yaitu suku bunga dan penawaran uang. Langkah bank sentral untuk menjalankan operasi terbuka dan mengubah rasio cadangan bank umum (perdagangan) adalah untuk mempengaruhi penawaran uang.

Sedangkan mengubah suku bunga diskonto atau Bank Rate adalah alat untuk mempengaruhi tingkat suku bunga. Namun kebijakan menetapkan suku bunga dan 
jumlah uang beredar tidak dapat dilaksanakan serentak sebab, perubahan yang satu dapat mempengaruhi perubahan yang lain. Sehingga dalam menjalankan kebijakan moneternya, bank sentral perlu memutuskan jenis variabel yang akan diawasi dan dikendalikan, apakah tingkat suku bunga atau penawaran uang. ${ }^{11}$

Menurut Sadono Sukirno, analisis kebijakan moneter dengan mempertahankan suku bunga melalui perubahan-perubahan penawaran uang ternyata akan menimbulkan fluktuasi yang besar dalam pendapatan nasional dan kegiatan ekonomi. Namun apabila kebijakan moneter melalui pengendalian jumlah penawaran uang maka efeknya terhadap kestabilan ekonomi lebih besar. ${ }^{12}$

\section{Kebijakan Moneter Islam}

Kebijakan moneter tidak diperlukan karena pada masa awal Islam hampir tidak ada sistem perbankan dan minimnya penggunaan uang. Kredit juga dianggap tidak memiliki peran dalam penciptaan uang, karena kredit hanya digunakan diantara para pedagang saja serta peraturan pemerintah tentang peminjaman (promissory notes) dan instrumen negosiasi dirancang sehingga tidak memungkinkan sistem kredit tersebut menciptakan uang. Surat berharga ini dapat diterbitkan untuk membeli barang dan jasa ataupun untuk mendapatkan dana segar, namun surat ini tidak dapat digunakan untuk kredit. Kreditur dapat menjual surat tersebut namun debitur tidak dapat menjualnya. Sehingga tidak terjadi spekulasi dan pasar uang. Aturan-aturan ini, memengaruhi keseimbangan antara pasar barang dan pasar uang berdasarkan uang tunai.

Transaksi seperti judi, riba, jual-beli superficial promissory notes dilarang dalam Islam sehingga keseimbangan arus uang dan barang/jasa dapat dipertahankan. Sistem yang diterapkan oleh pemerintah yang berhubungan dengan konsumsi, tabungan dan investasi serta perdagangan telah menciptakan instrumen otomatis untuk kebijakan moneter. Dan menjamin keseimbangan uang dan barang.jasa dan mencegah penggunaan tabungan selain untuk menciptakan kesejahteraan masyarakat. Adanya imbalan pahala dari Allah SWT untuk usaha dan kegiatan perekonomian lainnya menambahkan nilai untuk kaum muslimin. Al Qur'an memberi gambaran tentang perhatian kaum muslimin untuk penggunaan sumber daya yang telah disediakan 
150 |AT-TAWASSUTH: Jurnal Ekonomi Islam, Volume V No. 1

Januari - Juni 2020: 142 - 162

Allah SWT sehingga memperluas pandangan kaum muslimin untuk berpartisipasi dalam kegiatan perekonomian seperti investasi dan menyalurkan kekayaan melalui qard hasan ${ }^{13}$, infaq dan waqaf. ${ }^{14}$

\section{Operasi Moneter}

Operasi Moneter adalah pelaksanaan kebijakan moneter oleh Bank Indonesia dalam rangka pengendalian moneter melalui Operasi Pasar Terbuka dan Standing Facilities. Saat ini Bank Indonesia memiliki dua sistem moneter dalam melakukan pengendalian jumlah uang beredar. Yang pertama operasi moneter dengan instrumeninstrumennya seperti BI rate, Operasi Pasar Terbuka (OPT), dan sertifikat Bank Indonesia (SBI). Yang kedua, Bank Indonesia menambah operasi moneter yang dinamakan Operasi Moneter Syariah (OMS). Berdasarkan peraturan yang dikeluarkan Bank Indonesia nomor 16/12/PBI/2014 tanggal 24 Juli 2014, OMS ini memiliki beberapa instrumen di antaranya operasi pasar terbuka syariah (OPTS), transaksi penempatan berjangka syariah, dan Sertifikat Bank Indonesia Syariah (SBIS).

\section{Operasi Moneter di Indonesia}

Kebijakan moneter difokuskan pada pengendalian jumlah uang beredar sebagaimana yang dilaksanakan saat ini, Bank Indonesia menetapkan uang primer atau komponennya sebagai sasaran operasional dan jumlah uang beredar baik dalam arti sempit maupun luas sebagai sasaran.

Dalam hal kebijakan moneter difokuskan pada pengendalian suku bunga, Bank Indonesia menetapkan suku bunga pasar uang jangka pendek sebagai sasaran operasional. Untuk mencapai sasaran operasinal tersebut baik dalam kerangka kebijakan moneter berdasarkan sasaran kuantitas maupun sasaran suku bunga, Bank Indonesia dapat melakukan pengendalian moneter melalui OPT yang bersifat kontraksi atau ekspansi.

Saat ini OPT dilaksanakan oleh Bank Indonesia melalui instrumen operasional utama berupa penerbitan SBI melalui lelang SBI dan penyediaan fasilitas simpanan yang dikenal dengan FASBI. ${ }^{15}$ 


\section{Kerangka Pemikiran}

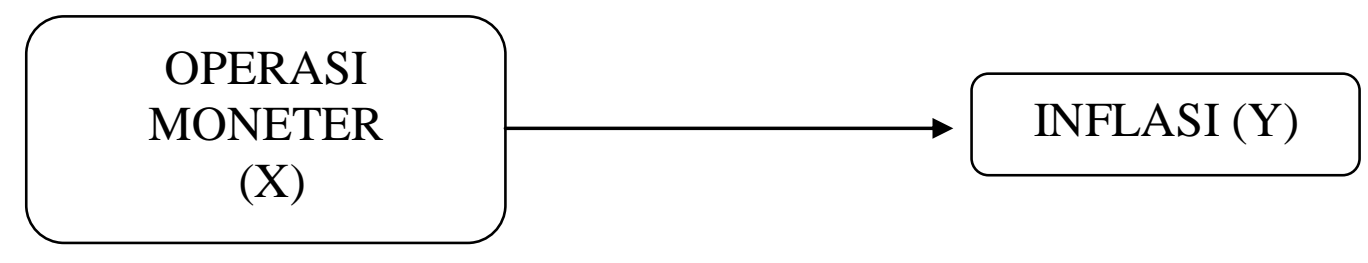

Gambar 1. Kerangka Pemikiran

\section{Hipotesis}

H0 : Bahwa Operasi Moneter tidak berpengaruh positif signifikan terhadap Inflasi

H1 : Bahwa Operasi Moneter berpengaruh positif signifikan terhadap Inflasi

\section{Metodologi Penelitian}

Jenis penelitian ini merupakan penelitian kuantitatif. Sumber data dalam penelitian ini adalah data sekunder merupakan data yang telah dikumpulkan oleh lembaga pengumpul data dan dipublikasikan kepada masyarakat pengguna data. ${ }^{16}$ Instrumen pengumpulan data pada penelitian ini menggunakan data sekunder runtun waktu (time series) yang mana diperoleh dari Bank Indonesia. Data yang dikumpulkan yaitu dari Januari 2017 - Mei 2020. Metode analisis data yang digunakan dalam penelitian ini, yaitu metode analisis regresi linier sederhana.

\section{Uji Asumsi Klasik}

Dalam penggunaan regresi, menuru Gujarati (1998) terdapat asumsi dasar yang terpenting sebagai syarat penggunaan metode regresi. Dengan terpenuhinya asumsi tersebut, maka hasil yang diperoleh dapat lebih akurat dan mendekati atau sama dengan kenyataan. Asumsi tersebut adalah asumsi tentang normalitas, multikolinearitas, dan autokorelasi. ${ }^{17}$

\section{Uji Regresi}

Menurut Gujarati (1988), metode yang digunakan untuk menguji hipotesis pada model regresi berganda, yaitu dengan menetukan tingkat dan menggunakan uji simultan (Uji Ftest dan R2 ) dan Uji parsial (Uji t-test) sebagai berikut :

Uji Determinasi (R2 ) digunakan untuk mengukur sejauh mana kemampuan model dalam menerangkan variasi variabel dependen. Nilai koefisien determinasi 
152 AT-TAWASSUTH: Jurnal Ekonomi Islam, Volume V No. 1

Januari - Juni 2020: 142 - 162

adalah di antara nol dan satu. Uji t-test digunakan untuk menguji pengaruh Operasi Moneter terhadap Inflasi di Indonesia. Penelitian ini menggunakan SPSS 20.0 sebagai alat untuk menguji data.

\section{Hasil Penelitian}

\section{Deskripsi Variabel Dependen}

Variabel dependen dalam penelitian ini adalah Inflasi. Inflasi merupakan gejala kenaikan harga barang-barang yang bersifat umum dan terus menerus. Ini tidak berarti bahwa harga-harga berbagai macam barang itu naik dengan dengan persentase yang sama. Mungkin dapat terjadi kenaikan harga tersebut tidak bersamaan. Terdapat kenaikan harga umum barang secara terus menerus selama satu periode tertentu. Kenaikan yang terjadi hanya sekali saja, meskipun dengan persentase yang cukup besar bukanlah merupakan inflasi.Berikut adalah data Inflasi di Indonesia periode Januari 2017 sampai dengan Mei 2020 :

Tabel 3 Inflasi di Indonesia ( dalam \% )

\begin{tabular}{|l|l|l|l|l|}
\hline Bulan & 2017 & 2018 & 2019 & 2020 \\
\hline Januari & 3.49 & 3.25 & 2.82 & 2.68 \\
\hline Februari & 3.83 & 3.18 & 2.57 & 2.98 \\
\hline Maret & 3.61 & 3.40 & 2.48 & 2.96 \\
\hline April & 4.17 & 3.41 & 2.83 & 2.67 \\
\hline May & 4.33 & 3.23 & 3.32 & 2.19 \\
\hline Juni & 4.37 & 3.12 & 3.28 & \\
\hline Juli & 3.88 & 3.18 & 3.32 & \\
\hline Agustus & 3.82 & 3.20 & 3.49 & \\
\hline September & 3.72 & 2.88 & 3.39 & \\
\hline Oktober & 3.58 & 3.16 & 3.13 & \\
\hline November & 3.30 & 3.23 & 3.00 & \\
\hline Desember & 3.61 & 3.13 & 2.72 & \\
\hline
\end{tabular}

\section{Sumber : Bank Indonesia}


Dari data diatas dapat disajikan dalam bentuk statistic deskriptif sebagai berikut:

\section{Tabel 4 Statistik Deskriptif Inflasi di Indonesia}

\section{Descriptive Statistics}

\begin{tabular}{|l|l|r|r|r|r|}
\hline & $\mathrm{N}$ & Minimum & Maximum & \multicolumn{1}{c|}{ Mean } & \multicolumn{1}{c|}{ Std. Deviation } \\
\hline Inflasi & 41 & 2.19 & 4.37 & 3.2661 & .47449 \\
Valid N \\
(listwise)
\end{tabular}

\section{Sumber : Data Sekunder yang diolah dengan SPSS}

Dari tabel diatas dengan jumlah pengamatan selama 41 bulan dimulai dari bulan Januari 2017 sampai Mei 2020, dapat dilihat bahwa Inflasi di Indonesia terendah sebesar $2.19 \%$ yaitu pada bulan Mei 2020 dan Inflasi tertinggi di Indonesia sebesar $4.37 \%$ yaitu pada bulan Juni 2017.

\section{Deskripsi Variabel Independen}

Variabel Independen pada penelitian ini adalah Operasi Moneter. Operasi Moneter yang terbagi menjadi dua yaitu Operasi Moneter Konvensional dan Operasi Moneter Syariah. Operasi Moneter adalah pelaksanaan kebijakan moneter oleh Bank Indonesia dalam rangka pengendalian moneter melalui Operasi Pasar Terbuka dan Standing Facilities. Berikut adalah data Operasi Moneter Periode Januari 2017 sampai dengan Mei 2020.

\section{Tabel 5 Operasi Moneter (Milyar Rp)}

\begin{tabular}{|l|c|c|c|c|}
\hline Bulan & 2017 & 2018 & 2019 & 2020 \\
\hline Januari & 473.007 & 556.142 & 304.919 & 411.674 \\
\hline Februari & 460.727 & 539.752 & 286.027 & 443.067 \\
\hline Maret & 470.695 & 474.823 & 307.737 & 438.189 \\
\hline April & 441.215 & 380.151 & 329.209 & 405.333 \\
\hline May & 471.634 & 338.283 & 239.114 & 444.084 \\
\hline Juni & 383.507 & 306.219 & 328.729 & \\
\hline Juli & 507.007 & 328.257 & 308.955 & \\
\hline Agustus & 480.469 & 279.645 & 295.890 & \\
\hline
\end{tabular}


154 | AT-TAWASSUTH: Jurnal Ekonomi Islam, Volume V No. 1

Januari - Juni 2020: 142 - 162

\begin{tabular}{|l|c|c|c|l|} 
September & 503.689 & 302.033 & 302.040 & \\
\hline Oktober & 485.562 & 320.306 & 317.814 & \\
\hline November & 486.579 & 332.999 & 358.240 & \\
\hline Desember & 427.760 & 291.007 & 297.491 & \\
\hline
\end{tabular}

\section{Sumber : Bank Indonesia}

Tabel diatas dapat disajikan dalam bentuk statistic deskriptif sebagai berikut :

\section{Tabel 6 Statistik Deskriptif Operasi Moneter}

\section{Descriptive Statistics}

\begin{tabular}{|l|r|r|r|r|r|}
\hline & $\mathrm{N}$ & Minimum & Maximum & Mean & Std. Deviation \\
\hline $\begin{array}{l}\text { Operasi } \\
\text { Moneter } \\
\text { Valid N } \\
\text { (listwise) }\end{array}$ & 41 & 239.114 & 556.142 & 386.82878 & 85.498021 \\
\hline
\end{tabular}

\section{Sumber : Data Sekunder yang diolah dengan SPSS}

Dari penyajian tabel statistik deskritif diatas dapat dilihat bahwa operasi moneter tertinggi sebesar 556.142 Milyar Rupiah pada periode pengamatan Januari 2018, dan operasi moneter terendah sebesar 239.114 Milyar Rupiah pada periode pengamatan Mei 2019. Selanjutnya, nilai rata-rata operasi moneter sebesar 386.82878 Milyar Rupiah dengan standar deviasi sebbesar 85.498021.

\section{Uji Asumsi Klasik}

\section{Uji Multikolinearitas.}

Untuk mengetahui adanya multikolinearitas adalah dengan melakukan uji VIF (Variance Inflation Factor) yaitu jika nilai VIF tidak lebih dari 10 dan nilai tolerance tidak kurang dari 0,1 maka model dapat dikatakan terbebas dari multikolinearitas. Berdasarkan hasil pengolahan SPSS atas data yang diperoleh, dapat dilihat pada tabel berikut :

Tabel 7 Hasil Uji Multikolinearitas

\begin{tabular}{|ll|r|r|}
\hline \multirow{2}{*}{ Model } & \multicolumn{2}{|c|}{ Collinearity Statistics } \\
\cline { 2 - 4 } & \multicolumn{2}{|c|}{ Tolerance } & \multicolumn{2}{|c|}{ VIF } \\
\hline 1 & (Constant) & 1.000 & \\
& Operasi Moneter & & 1.000 \\
\hline
\end{tabular}

a. Dependent Variable: Inflasi 
Berdasarkan data diatas dapat disimpulkan bahwa :

a. Hasil perhitungan nilai toleransi menunjukkan variable bebass yang memiliki nilai lebih dari 0,1 yang berarti tidak terjadi multikolinearitas, yaitu: 1,000

b. Hasil perhitungan nilai variance inflation factor (VIF) menunjukkan tidak ada variable bebas yang memiliki nilai VIF lebih dari 10, dimana nilai VIF sebesar 1,000 .

\section{Uji Autokorelasi}

Uji autokorelasi bertujuan untuk menguji apakah dalam suatu model regresi linier ada korelasi antara kesalahan pengganggu pada periode sekarang dengan periode sebelumnya. Model regresi yang baik adalah yang terbebas dari autokorelasi. Untuk melihat ada tidaknya autokorelasi adalah dengan menggunakan uji Durbin-Watson (Uji DW). Berikut adalah hasil pengujian Durbin-Watson dengan menggunakan program SPSS:

Tabel 8 Hasil Pengujian Durbin-Watson

\begin{tabular}{|c|}
\hline Durbin-Watson \\
\hline 1.590 \\
\hline
\end{tabular}

\section{Sumber: Data sekunder yang diolah}

Dari tabel diatas terlihat bahwa nilai Durbin-Watson adalah sebesar 1,590. Nilai Durbin-Watson berdasarkan tabel dengan derajat kepercayaan sebesar 5\% adalah dL sebesar 1,45 dan dU sebesar 1,55, sehingga nilai 4-dU adalah 2,45. Suatu persamaan regresi dikatakan terbebas dari autokorelasi apabila nilai Durbin-Watson terletak diantara dU dan 4-dU. Nilai Durbin-Watson pada penelitian ini adalah 1,590 yang berarti bahwa nilai tersebut terletak diantara dU dan 4-dU atau terletak pada 1,552,45. Maka model persamaan regresi ini menunjukkan tidak adanya autokorelasi.

\section{Uji Normalitas}

Uji normalitas digunakan untuk mengetahui apakah dalam sebuah model regresi, variabel dependen, variabel independen, atau keduanya mempunyai distribusi normal atau tidak. Model regresi yang baik adalah distribusi data normal atau mendekati normal. Untuk menguji normal data ini menggunakan metode analisis grafik dan melihat normal probability plot. Berikut hasil olah data dengan SPSS : 
156 AT-TAWASSUTH: Jurnal Ekonomi Islam, Volume V No. 1

Januari - Juni 2020: 142 - 162

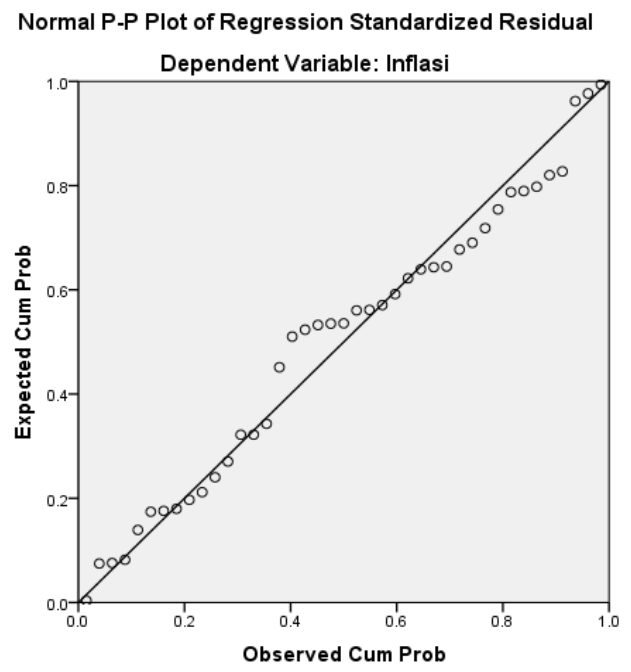

\section{Gambar 2. Normal Probability Plot}

\section{Sumber : Data sekunder yang diolah}

Dari gambar diatas terlihat bahwa sebaran data tersebar disekitar garis diagonal, maka dapat disimpulkan bahwa prasyarat normalitas terpenuhi. Hal ini mendukung hasil pengujian dengan menggunakan kolmogorov-smirnov test yang telah dilakukan sebelumnya.

Hasil pengujian normalitas juga didukung dengan uji Kolmogorov-smirnov test (K-S). Berikut hasil uji normalitas yang disajikan pada tabel berikut:

Tabel 9 Hasil Uji Normalitas Kolmogorov-Smirnov

\begin{tabular}{|c|c|c|}
\hline & & $\begin{array}{c}\text { Unstandardized } \\
\text { Residual }\end{array}$ \\
\hline $\mathrm{N}$ & & 41 \\
\hline Tonma,b & Mean & $0 \mathrm{E}-7$ \\
\hline IVOnImal ralanteles & Std. Deviation & .43788458 \\
\hline & Absolute & .120 \\
\hline Most Extreme Differences & Positive & .097 \\
\hline & Negative & -.120 \\
\hline Kolmogorov-Smirnov Z & & .769 \\
\hline Asymp. Sig. (2-tailed) & & .595 \\
\hline
\end{tabular}

a. Test distribution is Normal.

b. Calculated from data.

Sumber : Data sekunder yang diolah 
Pada hasil pengujian Kolmogorov Smirnov terlihat bahwa nilai signifikansi uji tersebut lebih besar dari 0,05 yaitu sebesar 0,769. Hal ini menandakan bahwa data yang digunakan dalam regresi berdistribusi normal. Sehingga dari hasil perhitungan ini menunjukkan bahwa data yang diperoleh dapat digunakan sebagai bahan penelitian.

\section{Uji Statistik}

\section{Uji t Statistik}

Pengujian terhadap koefisien regeresi dilakukan dengan uji t. Pengujian ini dilakukan untuk mengetahui signifikansi peran secara parsial antara variabel independen terhadap variabel dependen dengan mengasumsikan bahwa variabel independen lain dianggap konstan. Dengan tingkat signifikansi sebesar 95\%, nilai t hitung dari masing-masing koefisien regresi kemudian dibandingkan dengan nilai $\mathrm{t}$ tabel. Jika t-hitung $>$ t-tabel atau prob-sig $<\alpha=5 \%$ berarti bahwa masing-masing variabel independen berpengaruh secara positif terhadap variabel dependen.

Uji t statistik pada dasarnya menunjukkan seberapa jauh pengaruh satu variabel independen secara parsial dalam menerangkan variasi variabel dependen. Berikut hasil SPSS dari uji t yang dilakukan:

Tabel 10 Hasil Uji t Statistik

Coefficients $^{\mathrm{a}}$

\begin{tabular}{|c|c|c|c|c|c|}
\hline \multirow[t]{2}{*}{ Model } & \multicolumn{2}{|c|}{$\begin{array}{c}\text { Unstandardized } \\
\text { Coefficients }\end{array}$} & $\begin{array}{l}\text { Standardized } \\
\text { Coefficients }\end{array}$ & \multirow[t]{2}{*}{$\mathrm{t}$} & \multirow[t]{2}{*}{ Sig. } \\
\hline & B & Std. Error & Beta & & \\
\hline \multirow{2}{*}{$1 \begin{array}{ll}\text { (Constant }) \\
\text { Operasi Moneter }\end{array}$} & 2.439 & .325 & & 7.512 & .000 \\
\hline & .002 & .001 & .385 & 2.606 & .000 \\
\hline
\end{tabular}

a. Dependent Variable: Inflasi

\section{Sumber : Data sekunder yang diolah}

Dari tabel di atas dapat dilihat bahwa Operasi Moneter menunjukkan nilai t hitung sebesar 2,606 dengan signifikansi sebesar 0,000. Karena nilai signifikansi lebih kecil dari 0,05 dan nilai t hitung 2,606 lebih besar dari nilai t tabel 2.021, maka $\mathrm{H}_{0}$ ditolak dan $\mathrm{H}_{\mathrm{a}}$ diterima yang berarti bahwa terdapat pengaruh yang signifikan antara Operasi 
Moneter terhadap Inflasi di Indonesia. Artinya perubahan Operasi Moneter akan mempengaruhi besarnya Inflasi di Indonesia.

\section{Koefisien Determinasi Majemuk $\left(\mathbf{R}^{2}\right)$}

Koefisien determinasi majemuk $\left(\mathrm{R}^{2}\right)$ mengukur seberapa jauh kemampuan variabel independen dalam menerangkan variabel dependen. Nilai koefisien determinasi adalah diantara nol dan satu. Nilai $\mathrm{R}^{2}$ yang kecil berarti kemampuan variabel independen dalam menerangkan variabel dependen sangat terbatas. Nilai $\mathrm{R}^{2}$ mendekati satu berarti variabel independen memberikan hampir semua informasi yang dibutuhkan untuk memprediksi variasi variabel dependen.

Berikut adalah nilai koefisien determinasi dari penelitian ini yang diperoleh dari hasil output SPSS:

\section{Tabel 11 Hasil Koefisien Determinasi Majemuk $\left(\mathbf{R}^{2}\right)$}

\begin{tabular}{|l|r|r|r|c|}
\hline \multicolumn{6}{|c|}{ Model Summary $^{\mathbf{b}}$} \\
\hline 1 & $\mathrm{R}$ & R Square & Adjusted R Square & $\begin{array}{c}\text { Std. Error of the } \\
\text { Estimate }\end{array}$ \\
\hline 1 & $.887^{\mathrm{a}}$ & .786 & .773 & 273031,3041 \\
\hline
\end{tabular}

a. Predictors: (Constant), Operasi Moneter

b. Dependent Variable: Inflasi

\section{Sumber : Data sekunder yang diolah}

Tabel di atas menunjukkan nilai $\mathrm{R}$ square sebesar 0.786 . Hal ini menunjukkan bahwa operasi moneter mampu menerangkan inflasi sebesar 78,6 \%. Sedangkan sisanya sebesar $21,4 \%$ dijelaskan oleh variabel lain di luar model.

\section{Pembahasan}

Penelitian ini menggunakan 2 (dua) variabel, operasi moneter variabel bebas serta inflasi di Indonesia sebagai variabel terikat. Penelitian ini menggunakan data sekunder yang diperoleh dari data dokumentasi di Bank Indonesia.

Operasi Moneter adalah pelaksanaan kebijakan moneter oleh Bank Indonesia dalam rangka pengendalian moneter melalui Operasi Pasar Terbuka dan Standing Facilities. Saat ini Bank Indonesia memiliki dua sistem moneter dalam melakukan pengendalian jumlah uang beredar. Yang pertama operasi moneter dengan instrumen- 
instrumennya seperti BI rate, Operasi Pasar Terbuka (OPT), dan sertifikat Bank Indonesia (SBI). Yang kedua, Bank Indonesia menambah operasi moneter yang dinamakan Operasi Moneter Syariah (OMS). Berdasarkan peraturan yang dikeluarkan Bank Indonesia nomor 16/12/PBI/2014 tanggal 24 Juli 2014, OMS ini memiliki beberapa instrumen di antaranya operasi pasar terbuka syariah (OPTS), transaksi penempatan berjangka syariah, dan Sertifikat Bank Indonesia Syariah (SBIS).

Sebagaimana dikemukakan sebelumnya, dalam rangka mencapai sasaran kebijakan moneter Bank Indonesia dapat menerapkan kerangka kebijakan moneter melalui pengendalian jumlah uang beredar (sasaran kuantitas) atau suku bunga (sasaran suku bunga). Maka operasi moneter merupakan kebijakan yang menjadi pengendali inflasi di Indonesia.

Inflasi adalah gejala kenaikan harga barang-barang yang bersifat umum dan terus menerus. Ini tidak berarti bahwa harga-harga berbagai macam barang itu naik dengan dengan persentase yang sama. Mungkin dapat terjadi kenaikan harga tersebut tidak bersamaan. Terdapat kenaikan harga umum barang secara terus menerus selama satu periode tertentu. Kenaikan yang terjadi hanya sekali saja, meskipun dengan persentase yang cukup besar bukanlah merupakan inflasi.

Menurut para ekonom Islam, inflasi berakibat sangat buruk bagi perekonomian karena: Menimbulkan gangguan terhadap fungsi uang, terutama terhadap fungsi tabungan, fungsi dari pembayaran di muka, dan fungsi dari unit perhitungan. Melemahkan semangat menabung dan sikap terhadap menabung dari masyarakat. Meningkatkan kecenderungan untuk berbelanja terutama untuk non-primer dan barang- barang mewah. Mengarahkan investasi pada hal-hal yang non-produktif, yaitu penumpukkan kekayaan seperti : tanah, bangunan, logam mulia, mata uang asing dengan mengorbankan investasi kearah produktif seperti : pertanian, peternakan, pertambangan, industrial, perdagangan, transportasi, jasa dan lainnya.

Berdasarkan hasil penelitian dapat dilihat bahwa operasi moneter memiliki pengaruh yang signifikan terhadap inflasi di Indonesia. Dari hasil penelitian diatas, yang menyatakan bahwa operasi moneter sebesar 0,002. Artinya jika operasi moneter mengalami perubahan $1 \%$ maka akan menurunkan inflasi sebesar 0,002. 
160 |AT-TAWASSUTH: Jurnal Ekonomi Islam, Volume V No. 1

Januari - Juni 2020: 142 - 162

Berdasarkan hasil penelitian diperoleh bahwa hipotesis terbukti H0 ditolak dan $\mathrm{H} 1$ diterima, yaitu terdapat pengaruh operasi moneter terhadap inflasi di Indonesia periode Januari 2017 sampai dengan Mei 2020.

\section{Kesimpulan}

Besarnya pengaruh Operasi Moneter terhadap Inflasi jika terjadi kenaikan 1\% pada kebijakan Operasi Moneter maka akan menurunkan tingkat inflasi di Indonesia sebesar 0,002. Secara parsial variabel operasi moneter memiliki nilai p-value 0,000< 0,05 artinya signifikan. Sedangkan $t_{\text {hitung }} 2,606>2,021$ dari $t_{\text {tabel }}$ artinya signifikan. Maka operasi moneter berpengaruh terhadap inflasi di Indonesia.

\footnotetext{
Endnote

1 Suseno dan Siti Astiyah. Seri Kebanksentralan no.22 Inflasi, (Jakarta: PPSK Bank Indonesia, 2009), h. 2-3

${ }^{2}$ Bank Indonesia, https://www.bi.go.id/id/moneter/inflasi/data/Default.aspx diakses 18 Juli 2019

3 Dina Amalia, 3 Cara mengatasi Inflasi dengan kebijakan yang tepat, https://www.jurnal.id/id/blog/2017-3-cara-mengatasi-inflasi-dengan-kebijakan-yang-tepat/, 2017

${ }^{4}$ Perry, Warjiyo dan Solikin, Seri Kebanksentralan no.6 Kebijakan Moneter di Indonesia, (Jakarta: PPSK Bank Indonesia, 2003), h. 3-4

5 Khairina, Tambunan. (2016). Analisis Pengaruh Investasi, Operasi Moneter dan ZIS terhadap Pertumbuhan Ekonomi Indonesia, At-Tawassuth. 1(1). 73-94

${ }^{6}$ Bank Indonesia, https://www.bi.go.id/id/statistik/seki/terkini/moneter/Contents/Default.aspx diakses 18 Juli 2019

7 Khairina, Tambunan. (2016). Analisis Pengaruh Investasi, Operasi Moneter dan ZIS terhadap Pertumbuhan Ekonomi Indonesia, At-Tawassuth. 1(1). 73-94

${ }^{8}$ Faisal, Affandi. (2016). Analisis Pengaruh Tingkat Inflasi, Nilai Tukar, BI-Rate dan Suku Bunga Bank Konvensional terhadap Margin Bagi Hasil Deposito Mudarabah Perbankan Syariah Di Indonesia Periode 2010-2015. At-Tawassuth. 1(1). 45-72

${ }^{9}$ Nursantri, Yanti. (2018). Pengaruh SBI, SBIS, Inflasi dan Nilai Tukar Rupiah terhadap Transaksi Pasar Uang Antar Bank Syariah. At-Tawassuth. 3(1). 579-600

${ }^{10}$ Indris, Parakkasi. Inflasi dalam Perspektif Islam, (Makassar : UIN Alaudin, 2016), h. 44-47

11 John Maynard Keynes. The General Theory of Employment, interest, and money.(Florida: Harcourt Brace Jivanovich, 1953),h. 221

${ }^{12}$ Ibid, h. 202-207

13 Qard hasan (pinjaman kebaikan) yaitu pinjaman dengan kewajiban hanya pengembalian pinjaman pokoknya saja atau pihak menerima tidak wajib mengembalikan pinjaman karena kondisi force majeure (keadaan terpaksa atau di luar dugaan).

${ }_{14}$ Adiwarman A. Karim. Ekonomi Makro Islami.(Jakarta: PT RajaGrafindo Persada, 2010), h. $225-226$.

${ }^{15}$ F.X. Sugiono, Seri Kebansentralan no, 10 Instrumen Pengendalian Moneter Operasi Pasar Terbuka, Jakarta: PPSK Bank Indonesia, 2003), h.22-29

${ }^{16}$ Mudrajat Kuncoro, Metode Riset untuk Bisnis dan Ekonomi Edisi 3, (Jakarta: Erlangga,2009 ). h. 148

${ }^{17}$ Gujarati, Damodar Gujarati. Ekonometrika Dasar. Alih Bahasa : Drs. Ak. Sumarno Zain, MBA. (Jakarta: Erlangga, 1998)
} 
Nurul Jannah: Pengaruh Operasi Moneter Terhadap Inflasi Di Indonesia $\mid 161$

\section{Daftar Pustaka}

Abdul Karim, Adiwarman. (2010). Ekonomi Makro Islami. Jakarta: PT. RajaGrafindo Persada

Affandi, Faisal. (2016). Analisis Pengaruh Tingkat Inflasi, Nilai Tukar, BI-Rate dan Suku Bunga Bank Konvensional terhadap Margin Bagi Hasil Deposito Mudarabah Perbankan Syariah Di Indonesia Periode 2010-2015. AtTawassuth. 1(1). 45-72

Amalia, Dina. (2017). 3 Cara Mengatasi Inflasi Dengan Kebijakan Yang Tepat, https://www.jurnal.id/id/blog/2017-3-cara-mengatasi-inflasi-dengan kebijakan-yang-tepat/

Bank Indonesia, https://www.bi.go.id/id/moneter/inflasi/data/Default.aspx diakses 18 Juli 2019

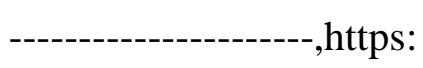

//www.bi.go.id/id/statistic/seki/terkini/moneter/Content/Default.aspx/.

Diakses 18 Juli 2019.

Efferin, Sujuko., dkk. (2008). Metode Penelitian Akuntansi. Yogyakarta: Graha Ilmu

Gujarati, Damodar Gujarati. (1988). Ekonometrika Dasar. Alih Bahasa : Drs. Ak. Sumarno Zain, MBA. Jakarta: Erlangga

Ghozali, Imam. (2005). Analisis Multivariate Dengan Program SPSS. Semarang: Penerbit UNDIP

Kuncoro, Mudrajat. (2009). Metode Riset Untuk Bisnis dan Ekonomi Edisi 3. Jakarta: Erlangga

Maynard Keynes. John. (1953). The General Theory Of Employment, Interest, And Money. Florida: Harcourt Brace Jivanovich

Parakkasi, Indris. (2016). Inflasi Dalam Perspektif Islam. Makassar: UIN Alaudin

Sugiono, F.X. (2003) Seri Kebansentralan no. 10 Instrumen Pengendalian Moneter Operasi Pasar Terbuka. Jakarta: PPSK Bank Indonesia

Suharyadi dan Purwanto S.K. (2009). Statistika: Untuk Ekonomi dan Keuangan Modern Edisi 2. Jakarta: Penerbit Salemba Empat 
162 AT-TAWASSUTH: Jurnal Ekonomi Islam, Volume V No. 1

Januari - Juni 2020: 142 - 162

Suseno dan Siti Astiyah. (2009). Seri Kebanksentralan no. 22 Inflasi. Jakarta: PPSK Bank Indonesia

Tambunan, Khairina. (2016). Analisis Pengaruh Investasi, Operasi Moneter dan ZIS Terhadap Pertumbuhan Ekonomi Indonesia. Medan: UIN SU

Warjiyo, Perry dan Solikin. (2003). Seri Kebanksentralan no. 6 Kebijakan Moneter di Indonesia. Jakarta: PPSK Bank Indonesia

Yanti, Nursantri. (2018). Pengaruh SBI, SBIS, Inflasi dan Nilai Tukar Rupiah terhadap Transaksi Pasar Uang Antar Bank Syariah. At-Tawassuth. 3(1). $579-600$ 